\title{
KARAKTERISTIK, MOTIVASI, DAN PERSEPSI WISATAWAN MANCANEGARA TERHADAP JASA PELAYANAN SHUTTLE BUS DI DAERAH UBUD, GIANYAR
}

\author{
I Putu Putrawan \\ Ni Made Sofia Wijaya \\ Luh Gede Leli Kusuma Dewi \\ Email : putrawan_p@gmail.com \\ PS. S1 Industri Perjalanan Wisata \\ Fakultas Pariwisata UNUD
}

\begin{abstract}
ABSTRAK
Saat ini sektor pariwisata di Ubud mengalami perkembangan dengan meningkatnya jumlah wisatawan (384.835 orang) yang menggunakan jasa pelayanan shuttle bus dari tahun 2011 sampai tahun 2015 pada perusahaan transportasi di Ubud. Shuttle bus merupakan transportasi publik yang melayani wisatawan dengan sistem sharing pick up dalam melakukan perjalanan ke tempat tujuan. Kemacetan di daerah pariwisata Ubud membuat wisatawan lebih cenderung memilih menggunakan pelayanan shuttle bus ke tempat tujuan wisata, maka ingin diketahui bagaimana karakteristik, motivasi dan persepsi wisatawan mancanegara terhadap jasa pelayanan shuttle bus di Ubud yang hasilnya diharapkan dapat menjadi masukan bagi perusahaan transportasi di Ubud khususnya dalam hal pelayanan kepada wisatawan mancanegara. Metode yang digunakan yaitu deskriptif dengan data kualitatif dan data kuantitaif, menggunakan data primer dan data sekunder, penentuan informan digunakan teknik purposive sampling untuk teknik pengambilan sampel secara accidental sampling melalui penyebaran 100 kuesioner kepada wisatawan mancanegara yang menggunakan pelayanan shuttle bus dan teknik analisis data yang digunakan adalah deskriptif kualitatif dan skala likert. Berdasarkan hasil penyebaran kuesioner diketahui bahwa karakteristik wisatawan mancanegara terhadap jasa pelayanan shuttle bus pada perusahaan shuttle bus di Ubud : bertujuan rekreasi berjumlah 87 orang $(87 \%)$, jenis kelamin perempuan berjumlah 55 orang $(55 \%)$, berusia 16 - - 30 tahun berjumlah 68 orang $(68 \%)$, belum menikah berjumlah 63 orang $(63 \%)$, pendidikan Universitas berjumlah 58 orang $(58 \%)$, berprofesi pegawai swasta berjumlah 43 orang $(43 \%)$, berasal dari negara Jerman berjumlah 28 orang $(28 \%)$, pendapatan rata-rata $\geq \$ 500$ berjumlah 64 orang $(64 \%)$ dan sumber informasi agen berjumlah 55 orang (55\%). Mempunyai motivasi terhadap harga murah daripull factor motivasi berjumlah 55 orang $(55 \%)$ dan persepsi wisatawan mancanegara terhadap jasa pelayanan shuttle bus adalah baik dengan jumlah total skor 4.598 dan rata-rata skor 45,98\%. Wisatawan mancanegara menggunakan jasa pelayanan shuttle bus di Ubud mayoritas wisatawan Eropa (28\%), mempunyai motivasi terhadap harga murah (55\%) dan mendapat persepsi pelayanan yang baik $(45,98 \%)$ dari perusahaan transportasi di Ubud. Untuk saran perlu penerapan SOP (Standar Operasional Prosedur) bagi sopir shuttle bus agar lebih mengoptimalkan pelayanan yang efektif kepada wisatawan.
\end{abstract}

Kata Kunci : Karakteristik, Motivasi, Persepsi, Pelayanan.

\section{PENDAHULUAN}

Perkembangan sektor pariwisata di Bali membuat peningkatan pembangunan akomodasi hotel, restoran, art shop, atraksi wisata dan perusahaan transportasi pada daerah wisata. Kabupaten Gianyar merupakan salah satu Kabupaten di Bali yang hingga kini menjadi lumbung daya tarik wisata seni dan budaya daerah. Sektor pariwisata di Kabupaten Gianyar relatif berkembang dengan berbagai produk kesenian di masing-masing 
daerah yang menjadi daya tarik wisata dan mampu mendatangkan kunjungan wisatawan mancanegara dan nusantara. Diketahui jumlah kunjungan wisatawan ke Kabupaten Gianyar (Sumber: Dinas Pariwisata Kab. Gianyar, 2015) dalam lima tahun terakhir mengalami peningkatan dari tahun 2010 sampai tahun 2014 dengan rata-rata pertumbuhan 9,19\%. Berdasarkan pertumbuhan tersebut, adanya peningkatan pembangunan sarana prasarana di Kabupaten Gianyar berdampak pada kemacetan khsusunya di Ubud. Berkembangnya sektor pariwisata di Ubud berdampak pada kemacetan dan menjadi masalah utama bagi wisatawan dalam melakukan perjalanan wisata. Adanya kemacetan di Ubud membuat wisatawan lebih cenderung menggunakan transportasi publik dalam melakukan perjalanan wisata. Salah satu transportasi publik yang berkembang di Ubud yaitu shuttle bus. Transportasi publik ini difungsikan mengurangi kemacetan dan melayani wisatawan dengan menggunakan sistem pelayanan sharing pick up yang mampu menampung wisatawan cukup banyak $( \pm 20$ orang) dalam menghantarkan wisatawan ke suatu tempat tujuan. Terdapat tiga perusahaan transportasi darat yaitu CV. Ubud Lestari Padma Transports, PT. Gedong Sari Tour and Travel, Gora Bali Transports yang berkembang cukup pesat dalam hal penyediaan jasa pelayanan shuttle bus. Tiga Perusahaan shuttle bus di Ubud (CV. Ubud Lestari Padma Transports, PT. Gedong Sari Tour and Travel dan CV. Gora Bali Transports) mengalami peningkatan pertumbuhan wisatawan pengguna jasa pelayanan shuttle bus dalam empat tahun terakhir dari tahun 2011 sampai tahun 2014 dengan rata-rata pertumbuhan $9,94 \%$ pada $C V$. Ubud Lestari Padma Transport, tahun 2011 sampai tahun 2014 dengan rata-rata pertumbuhan $10,05 \%$ pada PT. Gedong Sari Tour and Travel, tahun 2011 sampai tahun 2014 dengan rata-rata pertumbuhan 11,6\% pada CV. Gora Bali Transports (Sumber: $C V$. Ubud Lestari Padma Transports, PT. Gedong Sari Tour and Travel dan CV. Gora Bali Transports 2015). Berdasarkan peningkatan pertumbuhan wisatawan yang menggunakan jasa pelayanan shuttle bus pada tiga perusahaan shuttle bus diatas, maka menarik untuk diketahui mengenai karakteristik, motivasi, dan persepsi wisatawan mancanegara terhadap jasa pelayanan shuttle bus di Ubud. Untuk mengetahui karakteristik wisatawan digunakan konsep trip descriptor (karakteristik perjalanan wisatawan) dan tourist descriptor (karakteristik sosiodemografis, karakteristik geografis dan karakteristik sosio-ekonomi) (Seaton dan Bonnet, 1996 dalam Lucky Setiawan, 2014 : 15), motivasi wisatawan digunakan konsep push factor (kebutuhan internal) dan pull factor (kebutuhan eksternal) (Suntikul et al., 2010) dalam Seebaluck,Naidoo,Munhurrun dan Mungur (2013:147-148), Ryan (1991) dalam Pitana dan Gayatri (2005:67) dan Jakckson (1989) dalam Pitana dan Gayatri (2005 : 68) dan Persepsi wisatawan digunakan konsep fisik (kondisi objek) dan non fisik (jasa dan pelayanan) (Cahya Murti dan Sujali, 2013:246-266).

\section{METODE}

Metode yang digunakan adalah deskriptif dan teknik pengambilan digunakan rumus Slovin dalam Wicaksono (2012), sebagai berikut:

$n=\frac{N}{1+N e^{2}}$

Ket : $\mathrm{n}:$ ukuran sampel

$\mathrm{N}$ : Ukuran populasi

e : Nilai kritis

$\mathrm{e}^{2}: 0,1$ (ini berarti batas kesalahan yang

diinginkan hanya $10 \%$ dari batas

kesalahan tertinggi).

Berdasarkan rumus tersebut diketahui :

$\mathrm{n}=384.835$

$$
\text { Jadi } \quad \begin{aligned}
: \mathrm{n} & =\frac{384.835}{1+(384.835) 0,1^{2}} \\
& =\frac{384.835}{3.848} \\
& =100
\end{aligned}
$$

Berdasarkan hasil perhitungan rumus tersebut, maka dengan menyebarkan 100 kuesioner kepada wisatawan mancanegara yang menggunakan jasa pelayanan shuttle bus pada tiga perusahaan transportasi di Ubud dengan teknik pengambilan sampel secara accidental sampling dan teknik penentuan informan secara purposive. Teknik analisis data yang digunakan adalah analisis deskriptif kualitatif dan data kuantitaif diperoleh melalui skala likert dengan penggunaan rumus berikut :

Skor tertinggi - skor terendah Jumlah kelas $=$ Interval kelas 


$$
\frac{5-1}{5}=0,8
$$

(Slamet, 1993:19 (dalam Ni Nyoman

Sukmayanti 2005:33) sebuah laporan akhir)

Berdasarkan jumlah interval tersebut maka disusun kategori skala sikap wisatawan sebagai berikut :

Tabel 1

Skala Sikap Wisatawan

\begin{tabular}{|c|l|c|c|}
\hline \multirow{2}{*}{ No } & \multicolumn{3}{|c|}{ Skala Sikap Wisatawan } \\
\cline { 2 - 4 } & \multicolumn{1}{|c|}{ Sikap } & Skor & Kategori \\
\hline 1 & Sangat baik & 5 & $4,24-5,04$ \\
\hline 2 & Baik & 4 & $3,43-4,23$ \\
\hline 3 & Cukup & 3 & $2,62-3,42$ \\
\hline 4 & Buruk & 2 & $1,81-2,61$ \\
\hline 5 & Sangat buruk & 1 & $1,00-1,80$ \\
\hline
\end{tabular}

Sumber : Hasil modifikasi skala likert (Slamet, 1993:19 (dalam Ni Nyoman Sukmayanti 2005:33), sebuah laporan akhir).

\section{PEMBAHASAN}

Berdasarkan analisis data pada karakteristik wisatawan mancanegara pengguna jasa pelayanan shuttle bus di Ubud, adalah sebagai berikut :

\section{Tabel 2}

Karakteristik Wisatawan Mancanegara Pengguna Jasa Pelayanan Shuttle Bus di Ubud

\begin{tabular}{|l|l|l|c|}
\hline No & \multicolumn{1}{|c|}{ Karakteristik } & \multicolumn{1}{|c|}{ Dominan } & Presentase (\%) \\
\hline 1. & $\begin{array}{l}\text { Berdasarkan } \\
\text { Tujuan Berwisata }\end{array}$ & Rekreasi & $87 \%$ \\
\hline 2. & $\begin{array}{l}\text { Berdasarkan Jenis } \\
\text { Kelamin }\end{array}$ & Perempuan & $55 \%$ \\
\hline 3. & Berdasarkan Umur & $16--30$ tahun & $68 \%$ \\
\hline 4. & $\begin{array}{l}\text { Berdasarkan Status } \\
\text { Perkawinan }\end{array}$ & $\begin{array}{l}\text { Belum } \\
\text { Menikah }\end{array}$ & $63 \%$ \\
\hline 5. & $\begin{array}{l}\text { Berdasarkan } \\
\text { Pendidikan }\end{array}$ & Universitas & $58 \%$ \\
\hline 6. & $\begin{array}{l}\text { Berdasarkan } \\
\text { Pekerjaan }\end{array}$ & $\begin{array}{l}\text { Pegawai } \\
\text { Swasta }\end{array}$ & $43 \%$ \\
\hline 7. & $\begin{array}{l}\text { Berdasarkan } \\
\text { Daerah Asal }\end{array}$ & Jerman & $28 \%$ \\
\hline 8. & $\begin{array}{l}\text { Berdasarkan } \\
\text { Pendapatan }\end{array}$ & $\begin{array}{l}\geq 500 \\
\text { Berdasarkan } \\
\text { Sumber Informasi }\end{array}$ & Agen \\
\hline
\end{tabular}

Sumber : Data diolah dari hasil penelitian Agustus 2015

Berdasarkan tabel 2, karakteristik wisatawan mancanegara pengguna jasa pelayanan shuttle bus di Ubud adalah dominan dengan tujuan rekreasi $(87 \%)$, berjenis kelamin perempuan (55\%), kelompok umur 16--30 tahun (68\%), berstatus belum menikah (63\%), pendidikan Universitas (58\%), berprofesi sebagai pegawai swasta (43\%), berasal dari negara Jerman (28\%), pendapatan rata-rata $\geq \$ 500(54 \%)$ dan sumber informasi Agen (55\%).

Berdasarkan analisis data dari motivasi wisatawan mancanegara pengguna jasa pelayanan shuttle bus di Ubud, adalah sebagai berikut :

Tabel 3

Motivasi Wisatawan Mancanegara Pengguna Jasa Pelayanan Shuttle Bus di Ubud

\begin{tabular}{|c|l|c|}
\hline No & Push Factor Motivasi & Presentase (\%) \\
\hline 1. & Lebih aman & 4 \\
\hline 2. & $\begin{array}{l}\text { Lebih nyaman berinteraksi } \\
\text { dengan orang lain }\end{array}$ & 2 \\
\hline No & Pull Factor Motivasi & Presentase (\%) \\
\hline 1. & Harga murah & 55 \\
\hline 2. & Fasilitas bus memadai & 39 \\
\hline \multicolumn{2}{|c|}{ Jumlah } & 100 \\
\hline
\end{tabular}

Sumber : Data diolah dari hasil penelitian Agustus 2015

Berdasarkan tabel 3.1, motivasi wisatawan mancanegara pengguna jasa pelayanan shuttle bus adalah mayoritas pada motivasi harga murah (55\%).

Berdasarkan analisis data dari persepsi wisatawan mancanegara terhadap jasa pelayanan shuttle bus di Ubud, adalah sebagai berikut :

Tabel 4

Persepsi Wisatawan Mancanegara Terhadap Jasa Pelayanan Shuttle Bus di Ubud

\begin{tabular}{|c|c|c|c|c|c|c|}
\hline \multirow[t]{2}{*}{ No } & \multirow[t]{2}{*}{ Persepsi } & \multicolumn{5}{|c|}{ Kategori/Presentase (\%) } \\
\hline & & SB & B & $\mathrm{C}$ & B & SB \\
\hline 1. & $\begin{array}{l}\text { Kebersihan } \\
\text { Shuttle Bus }\end{array}$ & $34 \%$ & $54 \%$ & $12 \%$ & $0 \%$ & $0 \%$ \\
\hline 2. & $\begin{array}{l}\text { Keamanan } \\
\text { Shuttle Bus }\end{array}$ & $20 \%$ & $51 \%$ & $24 \%$ & $5 \%$ & $0 \%$ \\
\hline 3. & $\begin{array}{l}\text { Kenyamanan } \\
\text { Shuttle Bus }\end{array}$ & $24 \%$ & $36 \%$ & $30 \%$ & $7 \%$ & $3 \%$ \\
\hline 4. & $\begin{array}{l}\text { Fasilitas } \\
\text { Shuttle Bus }\end{array}$ & $10 \%$ & $26 \%$ & $57 \%$ & $5 \%$ & $2 \%$ \\
\hline 5. & $\begin{array}{l}\text { Ketepatan } \\
\text { Waktu } \\
\text { Pelayanan } \\
\text { Shuttle Bus }\end{array}$ & $19 \%$ & $33 \%$ & $41 \%$ & $6 \%$ & $1 \%$ \\
\hline 6. & $\begin{array}{l}\text { Sopan } \\
\text { Santun Sopir } \\
\text { Shuttle Bus } \\
\end{array}$ & $33 \%$ & $44 \%$ & $12 \%$ & $11 \%$ & $0 \%$ \\
\hline 7. & $\begin{array}{l}\text { Keramahan } \\
\text { Sopir Shuttle } \\
\text { Bus }\end{array}$ & $31 \%$ & $36 \%$ & $25 \%$ & $7 \%$ & $1 \%$ \\
\hline 8. & $\begin{array}{l}\text { Kemampuan } \\
\text { Sopir Shuttle } \\
\text { Bus Dalam } \\
\text { Penanganan } \\
\text { Keluhan }\end{array}$ & $25 \%$ & $37 \%$ & $35 \%$ & $1 \%$ & $2 \%$ \\
\hline 9. & $\begin{array}{l}\text { Kemampuan } \\
\text { Sopir Shuttle } \\
\text { Bus Dalam } \\
\text { Pemberian } \\
\text { Informasi }\end{array}$ & $10 \%$ & $60 \%$ & $21 \%$ & $7 \%$ & $2 \%$ \\
\hline 10. & $\begin{array}{l}\text { Kemampuan } \\
\text { Sopir Shuttle } \\
\text { Bus Dalam }\end{array}$ & $24 \%$ & $56 \%$ & $16 \%$ & $2 \%$ & $2 \%$ \\
\hline
\end{tabular}




\begin{tabular}{|c|l|c|c|c|c|c|}
\hline & Berkendara & & & & & \\
\hline 11. & $\begin{array}{l}\text { Kesediaan } \\
\text { Sopir Shuttle } \\
\text { Bus } \\
\text { Memberikan } \\
\text { Pertolongan }\end{array}$ & $34 \%$ & $55 \%$ & $8 \%$ & $2 \%$ & $1 \%$ \\
\hline 12. & $\begin{array}{l}\text { Kesediaan } \\
\text { Sopir Shuttle } \\
\text { Bus Dalam } \\
\text { Pengucapan } \\
\text { Salam }\end{array}$ & $28 \%$ & $42 \%$ & $24 \%$ & $6 \%$ & $0 \%$ \\
\hline
\end{tabular}

Sumber : Data diolah dari hasil penelitian Agustus 2015

Ket : SB : Sangat Baik

$$
\begin{aligned}
& \text { B : Baik } \\
& \text { C : Cukup } \\
& \text { B : Buruk }
\end{aligned}
$$

SB : Sangat Buruk

Berdasarkan tabel 4, persepsi wisatawan mancanegara terhadap jasa pelayanan shuttle bus di Ubud adalah persepsi terhadap kebersihan shuttle bus dikategorikan baik (54\%), persepsi terhadap keamanan shuttle bus dikategorikan baik (51\%), persepsi terhadap kenyamanan shuttle bus dikategorikan baik (36\%), persepsi terhadap fasilitas shuttle bus dikategorikan cukup (57\%), persepsi terhadap ketepatan waktu pelayanan shuttle bus dikategorikan cukup (41\%), persepsi terhadap sopan santun sopir shuttle bus dikategorikan baik (44\%), persepsi terhadap keramahan sopir shuttle bus dikategorikan baik (36\%), persepsi terhadap kemampuan sopir shuttle bus dalam penanganan keluhan dikategorikan baik (37\%), persepsi terhadap kemampuan sopir shuttle bus dalam pemberian informasi dikategorikan baik $(60 \%)$, persepsi terhadap kemampuan sopir shuttle bus dalam berkendara dikategorikan baik (56\%), persepsi terhadap kesediaan sopir shuttle bus memberikan pertolongan dikategorikan baik (55\%) dan persepsi terhadap kesediaan sopir shuttle bus dalam pengucapan salam dikategorikan baik $(42 \%)$.

Perusahaan shuttle bus di Ubud (CV. Ubud Lestari Padma Transports, PT. Gedong Sari Tour and Travel, Gora Bali Transports), bahwa karakteristik wisatawan mancanegara pengguna jasa pelayanan shuttle bus di Ubud adalah mayoritas dengan tujuan rekreasi (87\%) diakarenakan sebagaian besar wisatawan mancanegara mempunyai tujuan rekreasi berkunjung ke Ubud, berjenis kelamin perempuan $(55 \%)$ dikarenakan dominan wisatawan mancanegara (perempuan) lebih berkelompok menggunakan shuttle bus, kelompok umur 16--30 tahun (68\%) dikarenakan wisatawan mancanegara yang lebih muda lebih tertarik menggunakan shuttle bus, status perkawinan belum menikah (63\%) dikarenakan mayoritas wisatawan mancanegara yang belum menikah lebih suka berinteraksi dengan wisatawan lainnya dalam menggunakan shuttle bus, pendidikan Universitas (58\%) dikarenakan mayoritas wisatawan mancanegara yang menikmati liburan semester (Universitas) lebih dominan menggunakan shuttle bus, berprofesi sebagai pegawai swasta berjumlah (43\%) dikarenakan wisatawan mancanegara yang menikmati liburan semester (Univeritas) sambil bekerja sebagai pegawai swasta, berasal dari negara Jerman (28\%) dikarenakan wisatawan Jerman lebih suka berkelompok (keluarga) dalam menggunakan shuttle bus, pendapatan $\geq \$ 500$ (64\%) dikarenakan mayoritas wisatawan mancanegara berstatus mahasiswa menggunakan shuttle bus dan sumber informasi dari agen (55\%) dikarenakan banyak terdapat agen di Ubud (hotel dan tourist information).

Motivasi wisatawan mancanegara pengguna jasa pelayanan shuttle bus di Ubud adalah mayoritas mempunyai motivasi terhadap harga murah dari pull factor (55\%) dikarenakan pelayanan shuttle bus di Ubud menggunakan sistem sharing pick up dengan harga yang relatif murah.

Persepsi wisatawan mancanegara terhadap jasa pelayanan shuttle bus di Ubud adalah persepsi terhadap kebersihan shuttle bus dikategorikan baik (54\%) dengan jumlah keseluruhan sikapnya 425 dan rata-rata sikap 4,25 dikarenakan pembersihan shuttle bus dilakukan setiap hari, persepsi terhadap keamanan shuttle bus dikategorikan baik (51\%) dengan jumlah keseluruhan sikapnya 389 dan rata-rata sikap 3,89 dikarenakan sebagian besar shuttle bus tersedia safety belt dan terdapat beberapa shuttle bus yang tidak tersedia seafety belt, persepsi terhadap kenyamanan shuttle bus dikategorikan baik (36\%) dengan jumlah keseluruhan sikapnya 368 dan rata-rata sikap 3,68 dikarenakan sebagian besar shuttle bus tersedia long seat space dan terdapat beberapa shuttle bus yang tidak ada seat space, persepsi terhadap fasilitas shuttle bus dikategorikan cukup (57\%) dengan 
jumlah keseluruhan sikapnya 315 dan rata-rata sikap 3,15 dikarenakan sebagian besar shuttle bus tersedia AC (airconditioner) dan terdapat beberapa shuttle bus yang tidak tersedia AC (airconditioner), persepsi terhadap ketepatan waktu pelayanan shuttle bus dikategorikan cukup (41\%) dengan jumlah keseluruhan sikapnya 365 dan rata-rata sikap 3,65 dikarenakan shuttle bus menggunakan sistem pelayanan sharing pick up, persepsi terhadap sopan santun sopir shuttle bus dikategorikan baik (44\%) dengan jumlah keseluruhan sikapnya 400 dan rata-rata sikap 4 dikarenakan sebagian besar sopir berpengalaman melayani wisatawan dan terdapat beberapa sopir yang belum berpengalaman melayani wisatawan, persepsi terhadap keramahan sopir shuttle bus dikategorikan baik (36\%) dengan jumlah keseluruhan sikapnya 388 dan rata-rata sikap 3,88 dikarenakan sebagian besar sopir ramah terhadap wisatawan dan terdapat beberapa sopir yang tidak ramah terhadap wisatawan dan belum berpengalaman melayani wisatawan, persepsi terhadap kemampuan sopir shuttle bus dalam penanganan keluhan dikategorikan baik (37\%) dengan jumlah keseluruhan sikapnya 322 dan rata-rata sikap 3,22 dikarenakan sebagian besar sopir tanggap terhadap keluhan wisatawan dan terdapat beberapa sopir yang belum tanggap terhadap keluhan wisatawan, persepsi terhadap kemampuan sopir shuttle bus dalam pemberian informasi dikategorikan baik $(60 \%)$ dengan jumlah keseluruhan sikapnya 343 dan rata-rata sikap 3,43 dikarenakan sebagian besar sopir menguasai bahasa inggris dan terdapat beberapa sopir yang belum berpengalaman berbahasa inggris, persepsi terhadap kemampuan sopir shuttle bus dalam berkendara dikategorikan baik (56\%) dengan jumlah keseluruhan sikapnya 407 dan rata-rata sikap 4,7 dikarenakan sebagian besar sopir sudah berpengalaman mengendarai mini bus dan terdapat beberapa sopir yang belum berpengalaman mengendarai mini bus, persepsi terhadap kesediaan sopir shuttle bus memberikan pertolongan dikategorikan baik (55\%) dengan jumlah keseluruhan sikapnya 352 dan rata-rata sikap 3,52 dikarenakan sebagian besar sopir tanggap membantu wisatawan dan masih terdapat beberapa sopir yang belum tanggap membantu wisatawan dalam hal penurunan bagasi, persepsi terhadap kesediaan sopir shuttle bus dalam pengucapan salam dikategorikan baik (42\%) dengan jumlah keseluruhan sikapnya 391 dan rata-rata sikap 3,91 dikarenakan sebagian besar sopir ramah (greeting) terhadap wisatawan dan masih terdapat beberapa sopir yang belum ramah (greeting) terhadap wisatawan.

\section{SIMPULAN DAN SARAN Simpulan}

Berdasarkan hasil dan pembahasan yang telah dipaparkan, maka dapat diambil simpulan, sebagai berikut :

Karakteristik wisatawan mancanegara pengguna jasa pelayanan shuttle bus di Ubud adalah mayoritas dengan tujuan rekreasi, berjenis kelamin perempuan, berusia 16--30 tahun, berstatus belum menikah, tingkat pendidikan Universitas, berprofesi sebagai pegawai swasta, berasal dari negara Jerman, tingkat pendapatan rata-rata $\geq \$$ 500dan memperoleh sumber informasi melalui agen.

Motivasi wisatawan mancanegara terhadap jasa pelayanan shuttle bus di Ubud adalah mempunyai motivasi terhadap harga murah dari pull factor motivasi.

Persepsi wisatawan mancanegara terhadap jasa pelayanan shuttle bus di Ubud adalah dikategorikan baik dengan skor ratarata 45,98 .

\section{Saran}

Berdasarkan hasil dan pembahasan yang telah dipaparkan, maka dapat diberikan saran, sebagai berikut :

Bagi owner atau manager pada tiga perusahaan shuttle bus di Ubud (CV. Ubud Lestari Padma Transports, PT. Gedong Sari Tour and Travel, Gora Bali Transports) perlu meningkatkan promosi dan kerja sama dengan perusahaan lainnya, menerapkan standar keamanan, kenyamanan, fasilitas shuttle bus dan mengoptimalkan Standar Operasional Prosedur bagi karyawan untuk pertumbuhan wisatawan menggunakan shuttle bus dan selanjutnya dapat diperluas permasalahan terutama yang berhubungan dengan transportasi di daerah pariwisata.

\section{DAFTAR PUSTAKA}

Cahya Murti, Hestara dan Sujali. 2013. Persepsi Wisatawan Terhadap 
Pengembangan Obyek Wisata Batang Dolphin Center.UGM.Jurnal Pengembangan Obyek Wisata : Vol. 2, Nomor 2, 2013.

CV. Ubud Lestari Padma Transport, PT. Gedong Sari Tour and Travel dan CV. Gora Bali Transport. 2015. Data Jumlah Wisatawan Yang Menggunakan Jasa Pelayanan Shuttle Bus Di Tiga Perusahaan Transportasi Darat. Ubud, Gianyar-Bali.

Dinas Pariwisata Kabupaten Gianyar. 2015. Data Jumlah Kunjungan Wisatawan Mancanegara Dan Nusantara Ke Kabupaten Gianyar, Bali. GianyarBali.

Pitana, Prof. Dr. I Gd, M.Sc dan Gayatri, Ir. Putu G., M.Si. 2005. Sosiologi Pariwisata. Yogyakarta: ANDI.

Seebaluck, Vanessa. Naido, Perunjodi. Ramseook-Munhurrun, Prabha dan Mungur, Samer. 2013. An Evaluation Of Tourists Travel Motivation : Case Of Mauritius.Lecturer, University of Technology, Mauritius.Journal Global Conference on Business and Finance Proceedings : Vol. 8, No. 2, 2013.

Setiawan, Lukcy. 2014. "Karakteristik Dan Persepsi Wisatawan Terhadap Daya
Tarik Wisata Pantai Kata Di Kota Pariaman, Sumatera Barat”. (Skripsi). Denpasar : Program Studi Destinasi Pariwisata, Fakultas Pariwisata, Universitas Udayana.

Sukmayanti, Ni Nyoman. 2005. "Karakteristik Dan Motivasi Wisatawan Terhadap Pertunjukan Cabaret Show Di The Oriental, Kuta, Bali”. (Laporan Akhir). Denpasar : Program Studi D4, Fakultas Pariwisata, Universitas Udayana.

Wicaksono, R. 2012. Dalam http://analisis statistika.blogspot.com/2012/09/mene ntukan-jumlah-sampel-denganrumus.html. diunduh pada tanggal 5 April 2015. 